\title{
Manajemen Anestesi Stroke Perioperatif
}

\author{
Endah Permatasari"), Dewi Yulianti Bisri**), Siti Chasnak Saleh ${ }^{* * *}$, Himendra Wargahadibrata $\left.{ }^{* *}\right)$ \\ ${ }^{*}$ Departemen Anestesiologi dan Terapi Intensif RSU Kabupaten Tangerang, ${ }^{* *}$ Departemen Anestesiologi dan \\ Terapi Intensif Fakultas Kedokteran Universitas Padjadjaran - RSUP Dr.Hasan Sadikin-Bandung, ${ }^{* * *}$ Departemen \\ Anestesiologi dan Reanimasi Fakultas Kedokteran Universitas Airlangga-RSUD. Dr. Soetomo Surabaya
}

\begin{abstract}
Abstrak
Stroke perioperatif merupakan suatu kejadian katastropik yang meningkatkan mortalitas dan morbiditas, terutama pada usia di atas 65 tahun. Stroke perioperatif merupakan suatu momok (kejadian yang tidak diharapkan) bagi keluarga dan rekan sejawat yang merawat. Stroke perioperatif dapat bersifat iskemik atau hemoragik yang terjadi selama masa intraoperatif hingga 30 hari pascaoperasi. Faktor risiko terjadinya stroke perioperatif diantaranya adalah: usia lanjut, riwayat stroke dan Transient Ischemic Attack (TIA) sebelumnya, atrial fibrilasi, kelainan pembuluh darah dan metabolik. Umumnya stroke perioperatif tidak terjadi selama masa pembedahan atau saat pulih sadar, tetapi terjadi dalam 24 jam pertama pascabedah. Penanganan stroke perioperatif membutuhkan manajemen yang menyeluruh dan suatu kerjasama tim yang baik. Walaupun kejadiannya tidak banyak namun membutuhkan penanganan tepat karena tingkat morbiditas dan mortalitas yang tinggi serta mengakibatkan lama perawatan memanjang. Identifikasi awal pasien dan manajemen terpadu lintas keilmuan harus dilakukan untuk mencegah luaran yang buruk setelah terjadinya stroke perioperatif.
\end{abstract}

Kata kunci: faktor risiko, stroke perioperatif, anestesi

JNI 2018;7 (1): 54-61

\section{Anesthetic Management of Perioperative Stroke}

\begin{abstract}
Perioperative stroke can be a catastrophic outcome for surgical patients and is associated with increased morbidity and mortality, especially in the age above 65 . A perioperative stroke is an unexpected event for families and caring colleagues. A perioperative stroke may be an ischemic or haemorrhagic disorder that occurs intraoperatively or up to 30 days postoperatively. Risk factors for perioperative stroke include elderly, history of previous stroke and transient ischemic attack (TIA), atrial fibrillation, vascular and metabolic disorder. Most perioperative stroke generally does not occur during the intraoperative period or soon after recovering period but within the first 24 hours. Handling perioperative stroke requires a thorough management and a good teamwork. Perioperative stroke can be devastating, as they not only result in death but also prolong the length of hospital stay, increasing cost and greater likelihood of discharge to long term care facilities. Although the incidence is not much but this requires appropriate treatment because of high morbidity and mortality and also result in prolong length of hospital stay. Early identification and expeditious management involving a multidisciplinary approach is the key to avoid a poor outcome following perioperative stroke.
\end{abstract}

Key words: perioperative stroke, risk factor, anesthesia

JNI 2018;7 (1): 54-61 


\section{Pendahuluan}

Stroke perioperatif adalah salah satu komplikasi pembedahan yang paling ditakutkan. Stroke perioperatif terkait dengan peningkatan morbiditas dan mortalitas. Walaupun angka kejadian stroke perioperatif ini jarang, namun amat berpengaruh terhadap kualitas hidup pasien selanjutnya, keluarganya dan bagi dokter anestesi. Terkait aspek medikolegal apabila terjadi stroke perioperatif maka dokter anestesi harus siap agar tidak dianggap sebagai suatu kelalaian medik. ${ }^{1}$ Di Australia stroke merupakan penyebab kematian ketiga terbanyak, begitu juga di benua Amerika. Definisi stroke dari WHO adalah suatu kelainan yang ditandai dengan gejala fokal atau global gangguan perfusi serebral dengan gejala yang menetap dan lebih lama dari 24 jam sampai dapat menimbulkan kematian dengan penyebab utamanya kelainan pembuluh darah otak. Sedangkan Transient Ischemic Attack (TIA) merupakan suatu kelainan yang ditandai timbulnya defisit neurologis fokal secara tiba-tiba dan hilang dalam rentang waktu yang tidak lebih dari 24 jam. Sedangkan stroke perioperatif adalah stroke yang terjadi pada masa perioperatif, bisa selama pembedahan atau sampai dengan 30 hari pascabedah. ${ }^{1,2}$

\section{Faktor Risiko}

Untuk dapat melakukan tindakan pencegahan dan tatalaksana, dokter harus memahami berbagai faktor risiko selama masa perioperatif. Risiko untuk terkena stroke perioperatif berbanding lurus dengan dengan usia lanjut dan risiko tertinggi dijumpai pada pasien dengan usia lebih dari 84 tahun. Pada rentang usia di bawah 65 tahun, angka kejadian stroke perioperatif adalah 0,2-0,3\%. Risiko naik menjadi $0,5 \%$ pada rentang usia $65-80$ tahun. Di atas usia 80 tahun angka kejadian stroke perioperatif meningkat sampai dengan 3,4\%. Data ini menunjukkan komplikasi kardiovaskular yang berkaitan langsung dengan faktor umur. Riwayat hipertensi dan aritmia menjadi salah satu faktor penentu utama stroke perioperatif pada usia lanjut. Aritmia yang terbanyak adalah atrial fibrilasi. Hal ini menggambarkan penurunan cardiovascular reserve seiring dengan pertambahan usia. Perpaduan atrial fibrilasi dan kondisi hiperkoagulasi pascabedah menjadi faktor predisposisi timbulnya stroke perioperatif. Namun belum banyak informasi seputar stroke perioperatif yang sudah ada. Penelitian yang ada umumnya bersifat retrospektif sehingga angka kejadian yang sesungguhnya sebenarnya bisa lebih tinggi. Di masa depan, stroke perioperatif harus lebih diwaspadai karena meningkatnya usia harapan hidup dan meningkatnya populasi usia lanjut. ${ }^{1,3,4}$ Perpaduan faktor operasi dan anestesi merupakan suatu faktor penyebab stroke perioperatif. Risiko terkena stroke dapat meningkat sampai dengan enam kali lipat pada pasien yang dilakukan pembedahan dibandingkan populasi pada umumnya. Risiko lain yang penyebab terjadinya stroke perioperatif antara lain usia lanjut, riwayat stroke dan Transient Ischemic Attack (TIA) sebelumnya, atrial fibrilasi, kelainan pembuluh darah dan metabolik. Mortalitas stroke perioperatif meningkat sampai dengan dua kali lipat pada pasien dengan riwayat stroke dan TIA sebelumnya. Hal ini diduga karena diagnosis stroke perioperatif yang rancu akibat efek obat-obatan anestesi dan akibat proses inflamasi pascaoperasi. Dalam tabel 1 dan diagram 1 berikut akan dijabarkan faktor risiko stroke perioperatif. ${ }^{5,6,7}$ Meskipun teknik pembedahan dan perbaikan kondisi pasien pada masa perioperatif sudah berkembang maju, insiden stroke perioperatif tidak mengalami penurunan. Hal ini menggambarkan adanya peningkatan jumlah populasi penderita usia lanjut dengan berbagai komorbid yang membutuhkan tindakan pembedahan. Sekitar $85 \%$ penderita akan mampu melewati serangan pertamanya. Risiko terjadinya stroke perioperatif lebih tinggi pada kelompok masyarakat ini. Stroke perioperatif akan menyebabkan lama perawatan di rumah sakit memanjang, angka kecacatan, fase rehabilitasi yang lama dan peningkatan mortalitas pascabedah. ${ }^{3,4,7,8}$

Riwayat hipertensi, diabetes mellitus, gangguan fungsi ginjal (kreatinin lebih dari $2 \mathrm{mg} / \mathrm{dl}$ ), merokok, PPOK, penyakit serebrovaskular, Berdasarkan konsensus dari Society for Neuroscience in Anesthesiology and Critical Care (SNACC), stroke perioperatif dapat didefinisikan 
Tabel 1. Faktor risiko stroke perioperatif

\begin{tabular}{l}
\hline Faktor risiko praoperasi (patient related) \\
\hline Usia lanjut(> 70 tahun) \\
Jenis kelamin (perempuan) \\
Riwayat hipertensi, diabetes mellitus, gangguan fungsi ginjal (kreatinin lebih dari $2 \mathrm{mg} / \mathrm{dl})$, merokok, \\
PPOK, penyakit serebrovaskular, penyakit jantung (aritmia, CAD, gagal jantung) \\
Riwayat stroke atau transient ischemic attack \\
Stenosis karotis \\
Aterosklerosis aorta asenden \\
Penghentian tiba-tiba obat antikoagulan sebelum operasi \\
\hline Faktor risiko intraoperasi (procedure related) \\
\hline Prosedur operasi yang akan dilakukan \\
Teknik anestesi yang dilakukan \\
Waktu operasi yang dibutuhkan \\
Adanya aritmia, hiperglikemia, hipotensi dan hipertensi intraoperasi \\
\hline Faktor risiko pascaoperasi \\
\hline Timbulnya infarct miokard dan aritmia(atrial fibrilasi) \\
Kondisi dehidrasi dan kehilangan darah \\
Hiperglikemia \\
\hline Dikutip dari: Selim M.
\end{tabular}

sebagai suatu infark otak yang terjadi karena iskemia atau hemorragik yang terjadi selama pembedahan sampai dengan 30 hari pascabedah. Tidak seperti etiologi stroke pada komunitas, terdapat suatu mekanisme pencetus yang pasti pada kejadian stroke perioperatif yaitu intervensi pembedahan. Mekanisme stroke perioperatif antara lain atherothrombosis otak, emboli jantung karena atrial fibrilasi dan hipotensi. ${ }^{4,5,9}$

Angka kejadian stroke perioperatif pada pasien yang menjalani tindakan pembedahan jantung dan pembuluh darah serta neurologi lebih tinggi karena adanya penggunaan mesin bypass jantung-paru, manipulasi langsung jantung, otak dan pembuluh darah. Angkakejadian stroke perioperatif dapat dipengaruhi jenis dan kesulitan dari tindakan pembedahan. Risiko terjadinya stroke perioperatif lebih rendah pada anestesi umum dan bedah non kardiak, tetapi menjadi lebih tinggi pada bedah jantung dan pembuluh darah. Selain itu dikatakan stroke perioperatif lebih banyak terjadi pada kasus bedah gawat darurat dibandingkan pada kasus elektif. Bukti terakhir menunjukkan bahwa setiap satu pasien dari 1000 pasien yang dilakukan pembedahan dengan risiko yang minimal pun dapat mengalami stroke perioperatif dengan komplikasi mortalitas dan morbiditas yang bermakna. Angka kejadian stroke perioperatif berkisar antara $0,08 \%$ sampai dengan $2.9 \%$ namun tindakan pembedahan jantung, pembuluh darah dan otak memiliki angka kejadian stroke yang lebih tinggi, berkisar antara $2.2 \%$ sampai dengan 5.2\%. Pada pasien dengan riwayat gejala keluhan otak dan pembuluh darah (serebrovaskular) angka kejadian meningkat mencapai $13 \%$. Apabila terjadi stroke perioperatif tingkat kematian mencapai $26 \%{ }^{4,7,10,11}$

Sebelum dilakukan pembedahan harus dieveluasi ada tidaknya faktor risiko sehingga tindakan pencegahan dapat dilakukan dan dilakukan pertimbangan matang untuk evaluasi antara risiko yang mungkin terjadi dengan manfaat yang bisa dicapai (risk-benefit ratio). Selain persiapan perioperatif yang rutin dilakukan, pasien dapat dikonsultasikan ke teman sejawat neurologi bila diperlukan. Penanganan stroke perioperatif membutuhkan manajemen yang menyeluruh dan suatu kerjasama tim yang baik..$^{5,12,13}$ 


\section{Diagram 1. Faktor Risiko Stroke Perioperatif}

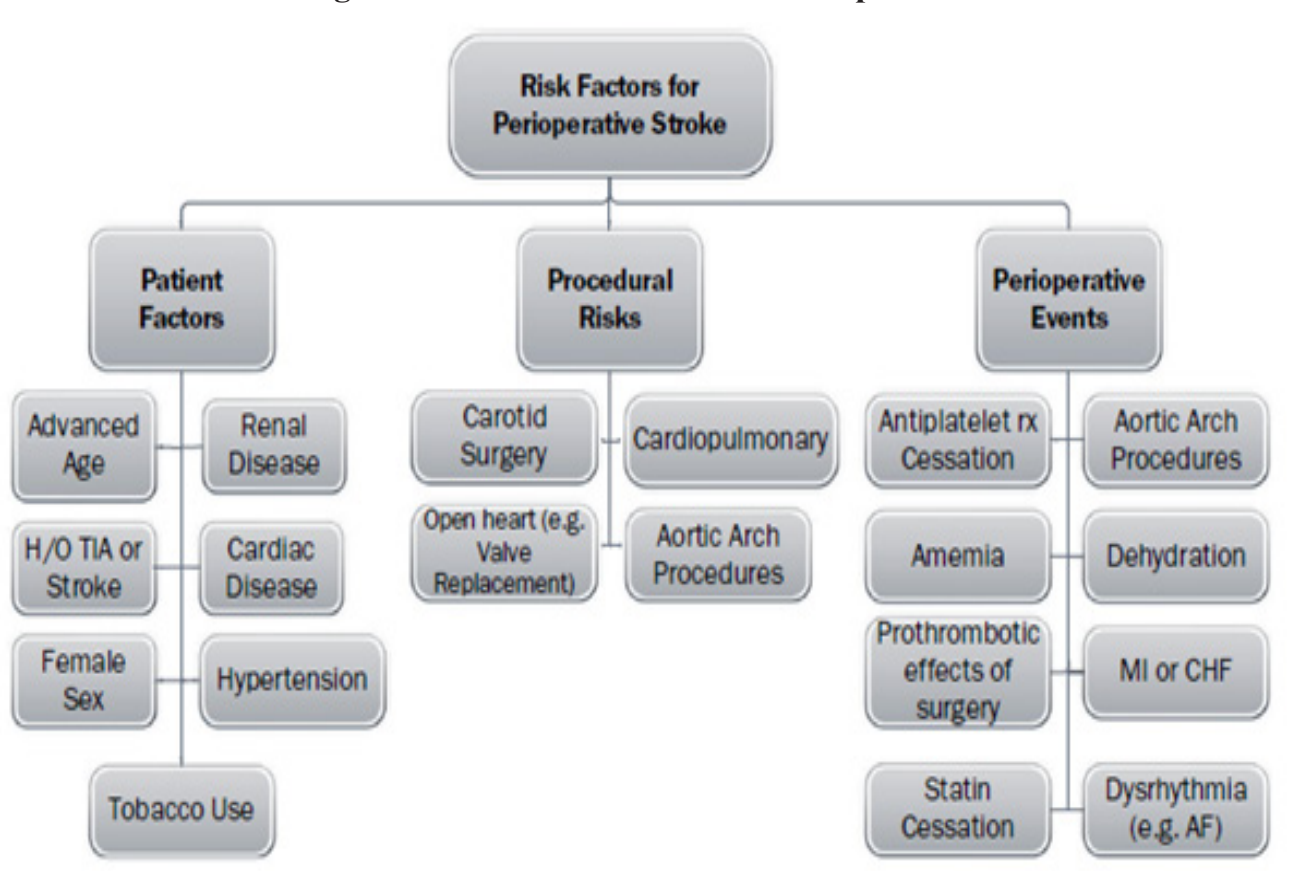

Dikutip dari: Lakshmanan RV et al. $2016 .^{6}$

\section{Patofisiologi Stroke Perioperatif}

Setiap tahunnya sekitar 6 juta orang meninggal karena stroke di seluruh dunia. Diperkirakan pada tahun 2030 penyakit serebrovaskular menjadi penyebab kematian no.2 di dunia. Sebagian besar stroke perioperatif adalah stroke iskemik. Angka kejadian stroke hemoragik berkisar hanya $1 \%$ dari total keseluruhan stroke perioperatif. Sebagian besar stroke perioperatif terjadi pada hari kedua setelah operasi. Dari berbagai penelitian yang melaporkan kejadian stroke perioperatif hanya 5,8\% dilaporkan terjadi selama pembedahan. Hal ini menggambarkan kemungkinan bahwa pascabedah terjadi mekanisme yang lebih penting dibandingkan pada saat selama pembedahan Faktor lain yang dianggap terkait dengan risiko terjadinya stroke perioperatif adalah kondisi hipotensi dan dehidrasi serta status hiperkaoagulasi pascabedah. Tirah baring pascabedah dan penghentian terapi antikoagulan juga mempengaruhi risiko timbulnya stroke perioperatif. Pembedahan darurat juga terkait dengan peningkatan risiko terjadinya stroke perioperatif. ${ }^{3,9,13}$ Diperkirakan lebih dari $60 \%$ stroke perioperatif pada kasus pembedahan jantung-paru (cardiothoracic) disebabkan karena adanya emboli. Sementara patofisiologi stroke perioperatif pada pembedahan non kardiak dan syaraf lebih sulit untuk diketahui penyebabnya multifaktor. ${ }^{3,12}$ Faktor risiko yang lazim ditemui pada stroke perioperatif antara lain usia lanjut, riwayat penyakit serebrovaskular, penyakit jantung iskemik, gagal jantung kongestif, fibrilasi atrium dan gangguan ginjal. Pada sekitar $30 \%$ kasus dengan stroke perioperatif dijumpai adanya atrial fibrilasi. Penyebab stroke yang jarang (tidak lazim) termasuk di antaranya adalah emboli udara, emboli lemak, thrombus dan infark medulla spinalis. Dalam tabel 2 dijabarkan angka kejadian stroke setelah berbagai tindakan pembedahan. ${ }^{1}$ Gejala klinis stroke dapat tidak tampak pada pasien dalam kondisi anestesi umum. Akan tetapi kebanyakan stroke terjadi pascabedah dimana pasien sudah tidak sedang dalam kondisi pembiusan. Sedasi yang berlebihan pada masa perioperatif dapat menutupi gejala stroke oleh karena itu sebaiknya dihindari. Stroke perioperatif yang terjadi sebagian besar adalah stroke iskemik, hanya sebagian kecil saja stroke hemorrhagik dan umumnya terjadi pascabedah. Pada pembedahan non kardiak dan bedah syaraf, 
Tabel 2. Angka Kejadian Stroke Pasca Berbagai Tindakan Pembedahan

\begin{tabular}{ll}
\hline Prosedur & $\begin{array}{l}\text { Risiko terjadinya } \\
\text { stroke(\%) }\end{array}$ \\
\hline Pembedahan minor & $0,08-0,7$ \\
Pembedahan vascular perifer & $0,8-3,0$ \\
Reseksi tumor kepala-leher & 4,8 \\
Karotis endarterektomi & $5,5-6,1$ \\
CABG & $1,4-3,8$ \\
Kombinasi CABG dan & $4,8-8,8$ \\
pembedahan katup jantung & \\
Pembedahan 2/3 katup jantung & 9,7 \\
Pembedahan repair aorta & 8,7 \\
\hline
\end{tabular}

Diambil dari: Selim M.?

stroke perioperatif dapat lebih lambat diketahui karena pasien sudah pindah rawat ke bangsal perawatan dan bukan di ICU. Berbeda dengan pasien pembedahan jantung, bedah syaraf dan vaskular yang bisa lebih awal diketahui karena pasien masih dalam perawatan di ICU dan dilakukan pengawasan ketat. ${ }^{3}$ Pasien dengan hipertensi yang tidak terkontrol dan pasien dengan riwayat terapi obat antikoagulan termasuk kelompok pasien risiko tinggi terjadinya stroke perioperatif. Etiologi stroke perioperatif termasuk diantaranya adalah adanya aneurisma intrakranial dan malformasi arteriovena. Pada aneurisma intrakranial dan malformasi arteriovena terjadi perubahan struktur pembuluh darah otak yang rentan pecah pada saat terjadinya fluktuasi tekanan darah mendadak terutama pada saat induksi dan ekstubasi anestesi. ${ }^{1,4}$

\section{Strategi Pencegahan Terjadinya Stroke Perioperatif}

Langkah awal untuk mencegah terjadinya stroke perioperatif adalah identifikasi pasien yang berisiko tinggi untuk mengalami stroke perioperatif dan melakukan optimalisasi kondisi sebelum dilakukan pembedahan untuk mengurangi komplikasi neurologis. Pada kelompok pasien yang sebelumnya memiliki riwayat kelainan serebovaskular harus dianggap memiliki risiko tinggi mengalami stroke perioperatif. Selama periode anestesi dan pembedahan harus dilakukan tindakan proteksi otak. Dokter anestesi memegang peran penting untuk melakukan proteksi otak dan mencegah terjadinya komplikasi neurologis. Komplikasi neurologis dari iskemia serebral selama pembedahan dapat berupa koma, kejang, stroke, delirium dan gangguan neurokognitif. ${ }^{1,4,6,13}$ Anestesi dan pembedahan dapat menyebabkan perubahan aliran darah otak dan autoregulasi otak. Ditambah dengan kondisi hiperkoagualasi pascabedah sehingga rentan terjadi iskemia otak pascabedah. Berdasar prinsip tersebut harus dilakukan langkah-langkah pencegahan terjadinya stroke perioperatif. ${ }^{4,13}$

\section{Prabedah}

Pada fase prabedah lakukan identifikasi faktor risiko dan optimalisasi penyakit penyerta (komorbiditas). Pasien dengan atrial fibrilasi, penyakit jantung koroner (CAD) dan hipertensi wajib dioptimalisasi terlebih dahulu sebelum tindakan pembedahan untuk mencegah terjadinya stroke perioperatif. Apabila terdapat kelainan atrial fibrilasi maka sebaiknya irama diupayakan menjadi sinus kembali dengan frekwensi yang normal. Pasien dengan diabetes mellitus sebelum tindakan pembedahan harus terkendali gula darahnya. Pasien dengan hipertensi yang tidak terkendali dan pasien dengan riwayat terapi obat antikoagulan termasuk kelompok pasien risiko tinggi mengalami stroke perioperatif. Kelompok pasien dengan terapi antikoagulan harus dilakukan pertimbangan matang untuk tetap melanjutkan terapi antikoagulan atau menunda sementara tindakan pembedahan. Pada masa pembedahan proses koagulasi dapat dipengaruhi oleh manipulasi tindakan pembedahan, pemberian cairan dan kehilangan darah. Trauma pembedahan dan cedera jaringan akan dapat menyebabkan proses inflamasi dan hiperkoagulasi. Kondisi hiperkoagulasi pascabedah merupakan kontributor utama stroke perioperatif. Obat-obat antikoagulan banyak diberikan pada pasien-pasien dengan risiko tinggi terkena stroke perioperatif untuk mengurangi risiko tromboemboli. Pada dekade sebelumnya ahli bedah akan langsung menghentikan terapi aspirin, clopidogrel dan warfarin untuk menghindari perdarahan selama pembedahan. 
Namun penghentian obat-obatan ini dapatmemicu kondisi hiperkoagulasi dan meningkatkan risiko terjadinya miokard infarct dan stroke iskemik. Obat antikoagulan harus segera diberikan apabila sudah diperbolehkan. ${ }^{4,5,6,7}$

Menjadi suatu pertimbangan khusus berapa lama pembedahan harus ditunda pada pasien yang baru mengalami stroke. Pada kondisi infark miokard sudah banyak kepustakaan yang menyebutkan bahwa sebaiknya pembedahan ditunda paling tidak 3 sampai 6 bulan. Namun tidak demikian pada pasien dengan riwayat stroke sebelumnya. Dalam suatu penelitian disebutkan bahwa tidak ada kaitan bermakna rentang waktu antara riwayat stroke sebelumnya dengan kemungkinan terjadinya stroke perioperatif. Berdasarkan konsensus dari SNSCC direkomendasikan untuk menunda operasi sampai dengan tiga bulan sesudah kejadian stroke sebelumnya untuk mencegah terjadinya stroke berulang. Apa peran anestesi dan pembedahan pada mekanisme stroke perioperatif? Anestesi umum dan pembedahan dapat menyebabkan gangguan autoregulasi otak, perubahan aliran darah otak, dan proses koagulasi pascabedah sehingga meningkatkan risiko terjadinya stroke perioperatif. Pada keadaan ini rentan untuk terjadi hipoperfusi otak terutama pada pasien-pasien dengan pembiusan umum. Dinamika selama pembedahan dapat terjadi perdarahan, anemia dan hipotensi. Diketahui stroke dapat mempengaruhi perubahan mekanisme autoregulasi otak yang dapat berlangsung sampai dengan berbulan-bulan sehingga meningkatkan risiko terjadinya iskemia otak. Selain meningkatkan risiko terjadinya stroke berulang juga akan meningkatkan risiko terjadinya komplikasi kardiovaskular. Namun tetap harus dipertimbangkan secara matang manfaat dan risikonya antara penundaan tindakan pembedahan dan risiko terjadinya stroke perioperatif bila dilaksanakan., ${ }^{1,-6}$

\section{Intrabedah}

Tindakan proteksi otak pada masa intrabedah dilakukan dengan pengendalian tekanan darah dan memastikan penghantaran oksigen yang cukup (optimal oxygen delivery). Rentang tekanan darah yang optimal selama pembedahan masih banyak diperdebatkan. Dalam suatu penelitian disebutkan bahwa pemantauan tekanan darah selama pembedahan harus diupayakan mendekati tekanan darah sebelum pembedahan. Perubahan tekanan darah yang melebihi dari 20 $\mathrm{mmHg}$ atau lebih dari $20 \%$ dari nilai normal prabedah dapat meningkatkan komplikasi perioperatif. Pengendalian tekanan darah selama pembedahan dan pascabedah untuk mendekati rentang nilai prabedah dapat mengurangi risiko stroke perioperatif dan kematian., ${ }^{4,7,9,13,14}$

Pemantauan ketat kadar gula darah pada masa perioperatif sangat penting Baik hiperglikemia ataupun hipoglikemia sama-sama dapat mempengaruhi tingkat keberhasilan operasi. Pencegahan hiperglikemia dan hipoglikemia wajib dilakukan pada pasien dengan riwayat diabetes mellitus. Meskipun pengendalian kadar gula darah secara ketat belum dapat dibuktikan memiliki efek perlindungan terhadap pencegahan terjadinya stroke perioperatif, hiperglikemia diketahui dapat memperburuk cedera otak (brain injury) dan menyebabkan peningkatan mortalitas pada kondisi iskemia serebral.

Kondisi hiperglikemia sebaiknya ditatalaksana apabila sudah lebih dari $150 \mathrm{mg} / \mathrm{dl}$ dan kadar gula darah yang tertinggi adalah $180 \mathrm{mg} /$ dl. Dengan target kadar gula darah antara 60-150 mg/dl. Untuk mencegah terjadinya hipoglikemia, dosis insulin harus dikurangi bila kadar gula darah mencapai $100 \mathrm{mg} / \mathrm{dl}$. Pada semua kasus dengan risiko tinggi terjadi stroke periopertif maka kadar gula darah harus selalu dipantau dan lakukan koreksi bila diperlukan., ${ }^{5,13}$ Obat anestesi inhalasi diketahui memiliki efek neuroproteksi terhadap iskemia otak pada penelitian binatang percobaan. Namun belum ada penelitian efek neuroproteksi obat anestesi inhalasi pada manusia. Gas anestesi inhalasi secara langsung memiliki efek dilatasi terhadap pembuluh darah otak sehingga mungkin dapat memperbaiki perfusi serebral. Kebalikannya obat-obat anestesi intravena seperti propofol dan thiopental dapat mengurangi aliran darah otak karena efeknya terhadap penurunan metabolisme otak. Pada pasien-pasien yang sudah dengan autoregulasi terganggu, kondisi 
ini dapat menyebabkan ketidaksesuaian aliran oksigen ke otak. Belum dapat dibuktikan apakah anestesi regional lebih baik daripada anestesi umum untuk mencegah stroke perioperatif. Namun pada tindakan pembedahan ortopedi esktremitas bawah (total knee replacement dan total hip replacement) anestesi regional lebih sedikit menyebabkan komplikasi stroke perioperatif dibandingkan anestesi umum. $., 7,13$ Saat ini masih terbatas data yang menunjukkan hubungan $\mathrm{PaCO}_{2}$ selama pembedahan dengan insiden stroke perioperatif. Meskipun belum ada bukti langsung yang menunjukkan teknik ventilasi selama pembedahan dengan risiko terjadinya stroke, hiperventilasi akan menyebabkan hipokapni yang berujung pada penurunan aliran darah otak hingga dapat timbul iskemia otak. Hiperventilasi dapat menyebabkan inverse steal phenomenon yang malahan akan meredistribusikan aliran darah dari area otak yang mengalami iskemia.

Teknik hiperventilasi selama pembedahan memiliki efek yang merugikan seperti penurunan oksigenasi, peningkatan kebutuhan oksigen jantung, disritmia dan penurunan aliran darah otak. Sehingga sebaiknya tidak dilakukan hiperventilasi pada pasien yang dengan riwayat stroke sebelumnya karena risiko penurunan aliran darah otak dan pertahankan kondisi normokapni bila memungkinkan. ${ }^{5,8,9,13}$ Semakin singkat lama pembedahan akan makin baik luaran hasil pembedahan dikaitkan dengan timbulnya risiko stroke perioperatif. Makin lama waktu pembedahan makin tinggi risiko timbulnya stroke perioperatif dan morbiditas lain. Manajemen anestesi yang baik berperan penting untuk mencegah terjadinya komplikasi serebral. ${ }^{8,9}$

\section{Pascabedah}

Kebanyakan stroke perioperatif terjadi pada masa pascabedah. Obat-obatan anestesi dan teknik anestesi dapat mempengaruhi insiden stroke perioperatif. Namun hingga kini belum ada penelitian prospektif yang ada. Lebih lanjut masih dibutuhkan penelitian berbagai faktor yang dapat menyebabkan stroke perioperatif. Hipotensi di masa pascabedah merupakan salah satu penanda stroke perioperatif dan harus dicegah agar tidak terjadi. Hiperkoagulasi pascabedah merupakan faktor potensial penyebab kejadian komplikasi serebrovaskular. Terapi antikoagulan harus segera diberikan apabila sudah diperbolehkan terutama pada pasien dengan atrial fibrilasi. ${ }^{3,4,6}$ Apabila terjadi lambat pulih sadar dari anestesi, perubahan status mental dan timbul defisit neurologis baru harus diwaspadai terjadinya suatu stroke perioperatif. Segera dilakukan langkah evaluasi untuk menyingkirkan terjadinya stroke perioperatif dan dilakukan pemeriksaan neuroradiologis bila diperlukan. Bila terjadi stroke perioperatif maka pasien harus dipantau dan diawasi di ruangan neuro critical care atau di unit perawatan stroke.

Pasien dikonsultasikan dan dirawat bersama dengan teman sejawat neurologi. Jalan nafas harus tetap dapat dipertahankan. Apabila nilai GCS dibawah 8 maka dilakukan intubasi untuk proteksi jalan nafas sekaligus untuk pencegahan terjadinya aspirasi lambung. Apabila diperlukan maka pemeriksaan neuroradiologis harus dilakukan. Hypercapnia harus di cegah, tekanan intrakranial harus dapat dikendalikan dan tatalaksana bila ada edema serebri. $\mathrm{SpO}_{2}$ harus dipertahankan di atas 94\% dengan pemberian oksigen dan ventilasi mekanik bila diperlukan. Irama jantung dipantau dengan monitor EKG kontinyu karena pasien stroke rentan untuk mengalami gangguan irama jantung. Analgesia diberikan bila dianggap ada rangsang nyeri karena nyeri dapat menimbulkan respon stress dan harus dicegah. ${ }^{2,5,6,13}$

\section{Simpulan}

Stroke perioperatif walaupun jarang ditemukan merupakan komplikasi perioperatif yang berat yang dapat menyebabkan peningkatan morbiditas dan mortalitas. Mengenali faktor risiko sangat penting dilakukan untuk mencegah terjadinya stroke perioperatif. Karena kebanyakan faktor risiko umumnya tidak dapat dihindari, tindakan pembedahan elektif pada pasien yang pernah mengalami stroke sebaiknya minimal ditunda hingga 3 bulan sambil menunggu membaiknya autoregulasi serebral. Pertimbangan antara melanjutkan atau menunda tindakan pembedahan dilakukan dengan seksama. 


\section{Daftar Pustaka}

1. Chiao SS, Zuo ZY. Approach to risk management of perioperative stroke. J Anesth Perioper Med 2015, 2:268-76.

2. Ng JL, Chan MT, Gelb WB. Perioperative stroke in noncardiac, nonneurosurg surgery. Anesthesiol 2011;115(4):879-90.

3. Kim Jarmila, Gelb AW. Predicting perioperative stroke. Journal of Neurosurgical Anesthesiology 1995;3:211-15.

4. Kam PCA, Calcroft RM. Peri-operative stroke in general surgical patients. Anaesthesia 1997: 52:879-83.

5. Mashour GA, Moore LE, Lele AV, Robicsek SA, Gelb AW. Perioperative care of patients at high risk for stroke during or after noncardiac, non-neurologic surgery: Consensus statement from the Society for Neuroscience in Anesthesiology and Critical Care. J Neurosurg Anesthesiol.2014;26:273-85.

6. Lakshmanan RV, Rajala B, Moore LE. Perioperative stroke. Curr Anesthesiol Rep 2016; 6: 202-13.
7. Selim M. Current concepts perioperative stroke. N Engl J Med 2007;356:706-13.

8. Gelb AB, Cowie DA. Perioperative stroke prevention. Anes \& Analg 2011;92:46-53.

9. Engelhard K. Anaesthetic techniques to prevent perioperative stroke. Curr Opin Anesthesiol 2013;26:368-74.

10. Szeder V, Torbey MT. Prevention and treatment of perioperative stroke. The Neurologist 2008;14(1):30-36.

11. Brooks DC, Schindler JL. Perioperative stroke: Risk assessment, prevention and treatment. Curr Treat Option Cardiovasc Med 2014;16(2):282-98.

12. Morales-Vidal S, Schneck M, Golombieski E. commonly asked questions in the management of perioperative stroke. Expert Rev Neurother 2013;13(2):167-75.

13. Abraham M. Protecting the anaesthetised brain. J Neuroanaesthesiol Crit Care 2014; $1: 20-39$.

14. Vlisides P, Mashour GA. Perioperative stroke. Can J Anaesth 2016;63(2):193-204. 